\section{Start-up of Autotrophic Nitrogen Removal Reactors via Sequential Biocatalyst Addition}

\author{
KRIS PYNAERT, BARTH F. SMETS, ${ }^{\dagger}$ \\ DAAN BEHEYDT, AND \\ WILLY VERSTRAETE*
}

Laboratory of Microbial Ecology and Technology (LabMET), Faculty of Agricultural and Applied Biological Sciences, Ghent University, Coupure Links 653, B-9000 Gent, Belgium

A procedure for start-up of oxygen-limited autotrophic nitrification-denitrification (OLAND) in a lab-scale rotating biological contactor (RBC) is presented. In this one-step process, $\mathrm{NH}_{4}{ }^{+}$is directly converted to $\mathrm{N}_{2}$ without the need for an organic carbon source. The approach is based on a sequential addition of two types of easily available biocatalyst to the reactor during start-up: aerobic nitrifying and anaerobic, granular methanogenic sludge. The first is added as a source of aerobic ammonia-oxidizing bacteria $(A A O B)$, the second as a possible source of planctomycetes including anaerobic ammonia-oxidizing bacteria ( $A \cap A O B$ ).

The initial nitrifying biofilm serves as a matrix for anaerobic cell incorporation. By subsequently imposing oxygen limitation, one can create an optimal environment for autotrophic $N$ removal. In this way, $N$ removal of about $250 \mathrm{mg}^{\circ} \mathrm{N} \mathrm{L}^{-1} \mathrm{~d}^{-1}$ was achieved after $100 \mathrm{~d}$ treating a synthetic $\mathrm{NH}_{4}{ }^{+}$-rich wastewater. By gradually imposing higher loads on the reactor, the $\mathrm{N}$ elimination could be increased to about $1.8 \mathrm{~g}$ of N L-1 $\mathrm{d}^{-1}$ at $250 \mathrm{~d}$. The resulting microbial community was compared with that of the inocula using general bacterial and $\mathrm{AAOB}$ - and planctomycete-specific PCR primers. Subsequently, the RBC reactor was show $n$ to treat a sludge digestor effluent under suboptimal and strongly varying conditions. The RBC biocatalyst was also submitted to complete absence of oxygen in a fixed-film bioreactor (FFBR) and proved able to remove $\mathrm{NH}_{4}{ }^{+}$with $\mathrm{NO}_{2}{ }^{-}$as electron acceptor (maximal $434 \mathrm{mg}$ of $\mathrm{NH}_{4}{ }^{+}-\mathrm{N}$ (g of VSS) ${ }^{-1} \mathrm{~d}^{-1}$ on day 136). DGGE and real-time PCR analysis demonstrated that the RBC biofilm was dominated by members of the genus Nitrosomonas and close relatives of Kuenenia stuttgartiensis, a known $A \cap A O B$. The latter was enriched during FFBR operation, but $A A O B$ were still present and the ratio planctomycetes/ AAOB rRNA gene copies was about 4.3 after $136 \mathrm{~d}$ of reactor operation. Whether this relates to an active role of $A A O B$ in the anoxic $N$ removal process remains to be solved.

\section{Introduction}

At present, the most commonly used approach for nitrogen (N) removal in wastewater treatment plants comprises a

* Corresponding author phone: +32 (0)926459 76; fax: +32(0)9 26462 48; e-mail: Willy.Verstraete@Ugent.be.

† Present address: Environmental Engineering and Microbiology Programs, University of Connecticut, Storrs, CT 06269-2037. combination of aerobic autotrophic nitrification of ammonium $\left(\mathrm{NH}_{4}^{+}\right)$to nitrite $\left(\mathrm{NO}_{2}^{-}\right)$and nitrate $\left(\mathrm{NO}_{3}^{-}\right)$and anoxic heterotrophic denitrification of theoxidized $\mathrm{N}$ species to dinitrogen gas $\left(\mathrm{N}_{2}\right)$. The first step is accomplished by two phylogenetically different groups of bacteria: the aerobic ammonia-oxidizing bacteria (AAOB) and the nitrite-oxidizing bacteria (NOB). The second step is carried out by a great variety of microorganisms and requires the concomitant availability of sufficient electron donors in the wastewater.

In some bioreactors treating highly nitrogenous wastewaters however, $\mathrm{N}$ deficits have been measured that could not be explained by this nitrification/ denitrification paradigm (1-3). Out of such reactors anaerobic ammonia-oxidizing bacteria (AnAOB) have been enriched (4). Two species retrieved from independent anoxic en richments, candidatus Brocadia anammoxidans(5) and Kuenenia stuttgartiensis(6), belong to a new, deep-branching group of Planctomycetales within the domain of the Bacteria. These enrichments are capable of autotrophic anaerobic $\mathrm{NH}_{4}{ }^{+}$oxidation (anammox) to $\mathrm{N}_{2}$ with $\mathrm{NO}_{2}^{-}$as the electron acceptor in the absence of molecular oxygen $\left(\mathrm{O}_{2}\right)$. In many of the aerated full-scale systems, the $\mathrm{N}$ removal was likely due to a close cooperation between $A A O B$ and $A n A O B$, the first producing one of the substrates $\left(\mathrm{NO}_{2}{ }^{-}\right)$for the second $(7,8)$. This concept of onestep autotrophic $\mathrm{N}$ removal from $\mathrm{NH}_{4}{ }^{+}$has been consecutively termed Oxygen-Limited Autotrophic NitrificationDenitrification (OLAND) (9-11), aerobic/anoxic de-ammonification (12), and Completely Autotrophic Nitrogen removal Over Nitrite (CANON; 13). These processes have a similar N removal stoichiometry and microbial composition. In the OLAND process, a supplementary, anoxic role of the AAOB in the biofilm is investigated. The two sequential reactions can also be obtained in two reactors in series: in an aerated first reactor a partial conversion of $\mathrm{NH}_{4}{ }^{+}$to $\mathrm{NO}_{2}{ }^{-}$is performed, while in an anoxic second reactor $\mathrm{NH}_{4}{ }^{+} / \mathrm{NO}_{2}{ }^{-}$is converted to $\mathrm{N}_{2}$. Several methods to halt aerobic nitrification at the point of $\mathrm{NO}_{2}{ }^{-}$and provide the influent stream to the second anoxic reactor have been described (14-16). Although both one- and two-reactor approaches reduce the costs for aeration and electron donor as compared to conventional nitrification-denitrification $(17,18)$, OLAND focuses on single-stage $\mathrm{N}$ removal in a biofilm reactor. The overall $\mathrm{N}$ removal stoichiometry for the described processes can be summarized by eqs $1-3$ :

nitritation: $\quad 1.3 \mathrm{NH}_{4}^{+}+1.95 \mathrm{O}_{2} \rightarrow 1.3 \mathrm{NO}_{2}^{-}+2.6 \mathrm{H}^{+}+1.3 \mathrm{H}_{2} \mathrm{O}$

anammox: $\quad \mathrm{NH}_{4}^{+}+1.3 \mathrm{NO}_{2}^{-} \rightarrow 0.26 \mathrm{NO}_{3}^{-}+1.02 \mathrm{~N}_{2}+2 \mathrm{H}_{2} \mathrm{O}$

$\mathrm{N}$ removal: $\quad \mathrm{NH}_{4}{ }^{+}+0.85 \mathrm{O}_{2} \rightarrow 0.11 \mathrm{NO}_{3}{ }^{-}+0.445 \mathrm{~N}_{2}+1.13 \mathrm{H}^{+}+1.43 \mathrm{H}_{2} \mathrm{O}$

Although autotrophic nitrification is a well-established process and the physiology of anammox has been intensively studied during the last couple of years, a reliable procedure for reactor start-up of single-stage autotrophic $\mathrm{N}$ removal processes has not yet been provided. Thelow specific growth rate (doubling time of around $10 \mathrm{~d}$; 4), and the so far unelucidated specific ecological requirements for AnAOB contributeto thischallenge. Herewe demonstratea stepwise procedure for initiation of OLAND, considering three main issues to obtain single-stage autotrophic N removal. First, the two types of biocatalyst need to be present. For the AAOB, a nitrifying enrichment culture (Ammonium Binding Inoculum Liquid, ABIL, Avecom, Beernem, Belgium) was chosen (19), grown at optimal temperatureand $\mathrm{pH}$ conditions on a synthetic $\mathrm{NH}_{4}{ }^{+}$-rich wastewater and mainly cultivated 
for use in aquaculture to prevent accumulation of $\mathrm{NH}_{4}{ }^{+}$. For the AnAOB, granular anaerobic biomass was used because anaerobic planctomycetes have been found in such environment (20). A second condition is that the two biocatalysts need to be in an environment where they can physically coexist. Due to the low and different specific growth rates, an attached growth reactor was considered. Finally, both groups of bacteria need to be in the right redoxenvironment. Oxygen is a necessity for the AAOB to produce $\mathrm{NO}_{2}^{-}$; however, it is (reversibly) inhibitory to the AnAOB (4). The amount of $\mathrm{O}_{2}$, however, has to be limiting to provide the AAOB with a competitive advantage over the NOB and to ensure continuous $\mathrm{NO}_{2}{ }^{-}$production in the system $(15,21)$. Biofilm reactors, which display gradients of many diffusiblespecies, may again provide this condition if the bulk oxygen concentration is carefully controlled. Ensuring a combination of these three factors should rapidly yield the desired configuration for autotrophic $\mathrm{N}$ removal.

The goals of this research were (i) to establish a robust start-up method to rapidlyyield stable, autotrophic $\mathrm{N}$ removal from $\mathrm{NH}_{4}{ }^{+}$in an aerated lab-scale biofilm reactor and demonstrate its ability to treat a real process wastewater; (ii) to test the biocatalyst of this reactor for $\mathrm{NH}_{4}{ }^{+} / \mathrm{NO}_{2}{ }^{-}$removal in an anoxic reactor; and (iii) to characterize the microbial communities that established in the aerobic and the anoxic reactor and compare them with the inocula, specifically in terms of dominant $\mathrm{AAOB}$ and planctomycetes.

\section{Materials and Methods}

Lab-Scale RBC Reactor. The reactor used was a slightly modified version of an earlier model $(10,11)$. Characteristics are as follows: basin length $=88 \mathrm{~cm}$, width $=34 \mathrm{~cm}$, height $=30 \mathrm{~cm}$, waterlevel at $19 \mathrm{~cm}$, total water volume $50 \mathrm{~L}$. Two groups of 20 poly(vinyl chloride) disks are mounted (diameter of one disk $=30 \mathrm{~cm}$, thickness $=0.5 \mathrm{~cm}, 1 \mathrm{~cm}$ interspace) on a horizontal shaft which rotates at $2.5 \mathrm{rpm}$ (low value chosen for $\mathrm{O}_{2}$ limitation), yielding $58 \%$ submergence of the disk surface area. The total surface area of the wetted disks and reactor walls was $6.3 \mathrm{~m}^{2}$. To increase the specific surface area for biofilm growth, a $5 \mathrm{~mm}$ layer of reticulated polyurethane (specific surface area $\pm 1000 \mathrm{~m}^{2} \mathrm{~m}^{-3}$, Type Filtren TM20, Recticel, Wetteren, Bel gium) was attached to one side of every disk. This increased the initial available surface area to about $20 \mathrm{~m}^{2}$.

Anoxic Fixed-Film Bioreactor (FFBR). The reactor used in these experiments was a closed cylindrical type (diameter: $13 \mathrm{~cm}$, height: $61 \mathrm{~cm}$, total volume $8.1 \mathrm{~L}$ ) FFBR, using a plastic carrier material (total surface area $\sim 0.5 \mathrm{~m}^{2}$ ) for biofilm growth (Figure 1). The liquid volume in the FFBR was $5 \mathrm{~L}$ and, including the carrier material, filled $66 \%$ of the total reactor volume. Temperature was $30 \pm 2^{\circ} \mathrm{C}$, no aeration was provided, influent flow was $1.33 \mathrm{~L} \mathrm{~d}^{-1}$, and feed composition $\left(\mathrm{NH}_{4}{ }^{+} / \mathrm{NO}_{2}{ }^{-}\right.$in a molar ratio of 1 ) was changed according to the reactor performance. The produced gas was collected in a 10-L gasbag connected to the headspace, emptied regularly, and flushed with Ar before re-installing on the reactor. The plastic carrier material was inoculated by submerging in the liquid volume of the RBC for 1 month to obtain biomass attachment and resubmerged completely in the FFBR liquid afterward. At the end of the experiment (day 136), the biofilm was gently removed from the carrier with a fine brush while washing with distilled water until no biomass was visibly present. Subsequently, the amount of TSS/ VSS in the reactor was determined, and specific aerobic and anoxic batch activity measurements were performed as described previously (22). Additional samples weretaken for microbial characterization. Batch activity measurementsand microbial characterization were also performed on RBC biomass from the end of the experiment (day 258) in order to compare biomass kinetics from the two reactors.

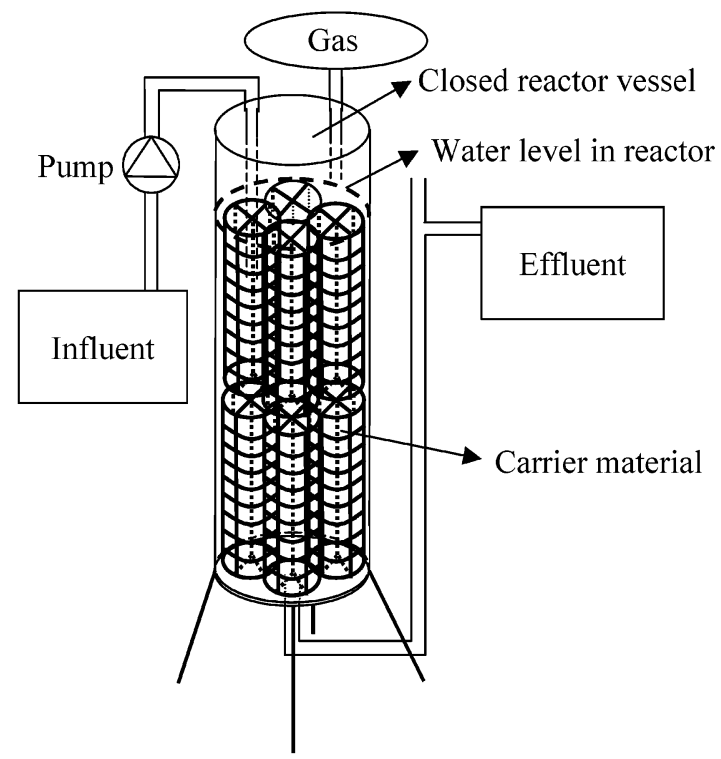

FIGURE 1. Scheme of the fixed-film bioreactor (FFBR). Cylindrical reactor made of plexiglass, total volume $8.1 \mathrm{~L}, 66 \%$ filled with liquid and carrier material (Bionet, $\left.\sim 100 \mathrm{~m}^{2} / \mathrm{m}^{3}\right)$, liquid volume $5 \mathrm{~L}(\sim 0.5$ $\mathrm{m}^{2}$ carrier surface). Flow through the reactor $\left(1.33 \mathrm{~L} \mathrm{~d}^{-1}\right)$ was dow nward.

Start-up Procedure of the RBC Reactor. Considering the specific requirements of both steps in the autotrophic $\mathrm{N}$ removal process $\left(\mathrm{NH}_{4}{ }^{+}\right.$plus $\mathrm{O}_{2}$ to $\mathrm{NO}_{2}^{-}$and $\mathrm{NH}_{4}{ }^{+}$plus $\mathrm{NO}_{2}{ }^{-}$ to $\mathrm{N}_{2}$ ), a strategy was developed to rapidly yield autotrophic $\mathrm{N}$ removal in a biofilm reactor. It comprised threecontrolled actions, separated by two periods of bacterial growth and biofilm development. The first action was the inoculation of $0.3 \mathrm{~g}$ of VSS $\mathrm{L}^{-1}$ of the actively nitrifying $(0.44 \pm 0.09 \mathrm{~g}$ of $\mathrm{N}$ oxidized (gof VSS) ${ }^{-1} \mathrm{~d}^{-1}$ ) ABI L culturefor growth of a nitrifying biofilm. The reactor feed during this period was buffered with $\mathrm{NaHCO}_{3}$ to maintain the $\mathrm{pH}$ between 7.8 and 8.0, and the reactor was installed in a temperature-controlled room at $30 \pm 1{ }^{\circ} \mathrm{C}$. During the whole experimental period, the $\mathrm{N}$ loading ratewas changed through variations in influent $\mathrm{NH}_{4}{ }^{+}$ concentration (Figure 2A) and flow rate (Figure 2B). Once a (thin) well-nitrifying biofilm had developed (based on visual perception of nearly continuous disk coverageand more than $98 \%$ conversion of $\mathrm{NH}_{4}{ }^{+}$to $\mathrm{NO}_{3}{ }^{-}$at a reactor load of $300 \mathrm{mg}$ of $\left.\mathrm{N} \mathrm{L}^{-1} \mathrm{~d}^{-1}\right)$, approximately $10 \mathrm{~L}(\approx 500 \mathrm{~g}$ of VSS or $625 \mathrm{~g}$ of COD-VSS) of granular anaerobic biomass from a full-scale upflow anaerobic sludge blanket reactor treating a potato processing wastewater (Primeur, Waregem, Belgium) was added to the reactor on day 47 (action 2). Subsequently, anaerobic cells and cell clusters were entrapped and overgrown in the nitrifying biofilm (visual perception). The third and final action was the controlled increase of the reactor load, thereby changing the bulk DO concentration and consequently the $\mathrm{O}_{2}$ profile in the biofilm (not directly measured in this study). The presence of $A A O B$ in $A B I L$ and planctomycetes in the granular anaerobic sludge was confirmed by the real-time PCR count of both groups of bacteria: $263 \pm 115 \times 10^{3}$ AAOB rRNA gene copies (ng of total DNA) ${ }^{-1}$ in $A B I L$ and $25 \pm 8 \times 10^{3}$ planctomycete rRNA gene copies (ng of total DNA) ${ }^{-1}$ in the anaerobic sludge(Table 1).

Synthetic Wastewater. A synthetic wastewater, prepared with tap water and containing $\left(\mathrm{NH}_{4}\right)_{2} \mathrm{SO}_{4}(\mathrm{~N}$ source) and $\mathrm{NaHCO}_{3}$ (C source and buffer), was fed to the RBC for 258 d. The influent $\mathrm{NaHCO}_{3}$ concentration varied depending on the needed buffer capacity, while the influent $\mathrm{NH}_{4}{ }^{+}$concentration and flow rate wereadjusted during the experiment to obtain the desired $\mathrm{N}$ load and hydraulic retention time 
TABLE 1. Overview of Reactor Performance, Batch-Measured Kinetics Tests, and Microbial Characteristics of the RBC and FFBR ${ }^{a}$

unit

volumetric $\mathrm{N}$ removal

specific anoxic $\mathrm{NH}_{4}^{+}$oxidation

anoxic reaction stoichiometry

specific aerobic $\mathrm{NH}_{4}{ }^{+}$oxidation specific anoxic $\mathrm{NH}_{4}^{+}$oxidation anoxic reaction stoichiometry
Reactor

mg of $\mathrm{N} \mathrm{L}^{-1} \mathrm{~d}^{-1}$

$\mathrm{mg}$ of $\mathrm{N}$ (g of VSS) $)^{-1} \mathrm{~d}^{-1}$

$\mathrm{NH}_{4}{ }^{+} / \mathrm{NO}_{2}^{-} / \mathrm{NO}_{3}^{-}$

$[\mathrm{N}] /[\mathrm{N}] /[\mathrm{N}]$

Batch Tests

mg of $\mathrm{N}$ (g of VSS) $)^{-1} \mathrm{~d}^{-1}$ mg of $N(g \text { of VSS })^{-1} d^{-1}$ $\mathrm{NH}_{4}{ }^{+} / \mathrm{NO}_{2}{ }^{-} / \mathrm{NO}_{3}{ }^{-}$

$[\mathrm{N}] /[\mathrm{N}] /[\mathrm{N}]$
$\mathrm{RBC}$

$\begin{array}{ll}1795 & 583 \\ \mathrm{nd}^{b} & 434 \\ \mathrm{nd}^{b} & -1 /-1.07 /+0.18\end{array}$

$175.2 \pm 14.4$

$117.6 \pm 16.8$

$-1 /-1.4 /+0.24$

$38.4 \pm 4.8^{c}$

$350.4 \pm 28.8$

$-1 /-1.17 /+0.19$

\begin{tabular}{|c|c|c|c|c|}
\hline \multirow[b]{2}{*}{ RT-PCR quantification } & \multicolumn{4}{|c|}{ rRNA gene copies $\mathrm{ng}^{-1}$ total DNA $\left(\times 10^{3}\right)$} \\
\hline & ABIL & $\mathrm{AnS}^{d}$ & RBC & FFBR \\
\hline $\begin{array}{l}\text { bacteria } \\
\text { AAOB } \\
\text { planctomycetes }\end{array}$ & $\begin{aligned} 734 & \pm 171 \\
263 & \pm 115 \\
10 & \pm 3\end{aligned}$ & $\begin{array}{r}200 \pm 9 \\
27 \pm 7 \\
25 \pm 8\end{array}$ & $\begin{array}{l}692 \pm 168 \\
146 \pm 80 \\
133 \pm 47\end{array}$ & $\begin{aligned} 417 & \pm 101 \\
35 & \pm 10 \\
153 & \pm 38\end{aligned}$ \\
\hline
\end{tabular}

$136 \mathrm{~d}) .{ }^{b}$ This ratio could not be directly determined due to simultaneous aerobic $\mathrm{N}$ conversion. ${ }^{c}$ Measured after a lag phase of $24 \mathrm{~h} .{ }^{d} \mathrm{Anaerobic}$ sludge from the Primeur potato processing wastewater treatment plant.

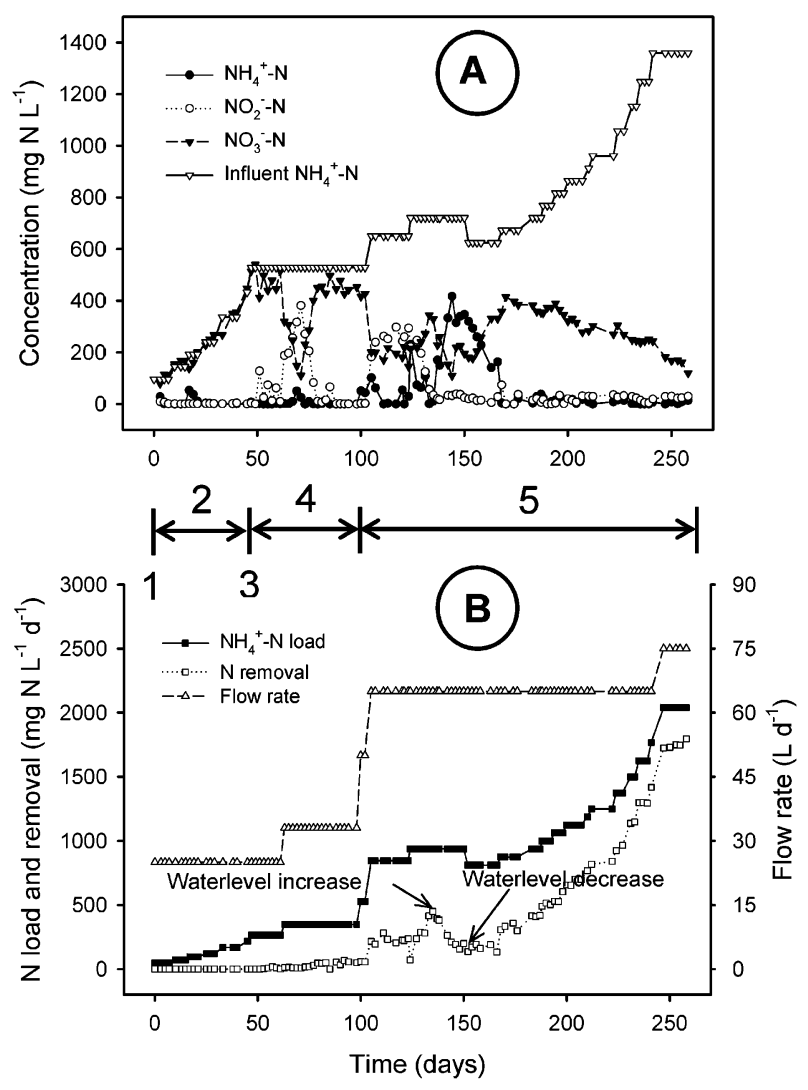

FIGURE 2. Performance of the RBC reactor during the five-step start-up procedure. (A) Effluent inorganic- $\mathrm{N}$ concentrations and influent $\mathrm{NH}_{4}{ }^{+}-\mathrm{N}$ concentrations. (B) Reactor $\mathrm{N}$ load and removal rate + influent flow rate: 1 , firstaction: inoculation w ith a nitrifying enrichment culture; 2 , period of nitrifying biofilm grow th; 3 , second action: addition of anaerobic biomass; 4 , period of presumed anaerobic cells and cell cluster entrapment in and overgrow th by the nitrifying biofilm; 5 , third action: oxygen limitation by load increase.

(HRT). In addition, the wastewater contained $0.07 \mathrm{~g}$ of phosphorus $(\mathrm{P}) \mathrm{L}^{-1}$ and $2 \mathrm{~mL} \mathrm{~L}^{-1}$ of a trace element solution (9), yielding a pH of 7.8. The feed for the anoxic FFBR consisted of a $\mathrm{NH}_{4}{ }^{+} / \mathrm{NO}_{2}^{-}$mixture (as $\mathrm{NH}_{4} \mathrm{Cl}$ and $\mathrm{NaNO}_{2}$, respectively), $1 \mathrm{~g} \mathrm{~L}^{-1} \mathrm{NaHCO}_{3}, 30 \mathrm{mg} \mathrm{L}^{-1} \mathrm{KH}_{2} \mathrm{PO}_{4}$, and $2 \mathrm{~mL}$
$\mathrm{L}^{-1}$ of the trace element solution. The $\mathrm{pH}$ was adjusted to 7.0 with $0.5 \mathrm{M} \mathrm{HCl}$ beforeaddition to the reactor. Feed solutions were delivered to both reactors with peristaltic pumps.

Treatment of a Sludge Digestor Effluent. After the period on the synthetic wastewater, the lab-scale RBC reactor was used to treat a full-scalesludge digestor effluent (Schijnpoort, Aquafin Deurne, Belgium). The latter is dewatered in two centrifuges, and part of the centrifugate was collected in a $1-\mathrm{m}^{3}$ tank for post-sedimentation (to remove some of the suspended solids and avoid clogging of tubing) before it was pumped to the lab-scale RBC. The RBC was placed in an outsidecontainer, without temperature or $\mathrm{pH}$ control. During transportation from the anaerobic digestors to the RBC reactor, the temperature, $\mathrm{DO}$, and $\mathrm{pH}$ of the wastewater changed to an average value of respectively $22.4 \pm 1.9^{\circ} \mathrm{C}$, $5.62 \pm 0.78 \mathrm{mg}$ of $\mathrm{O}_{2} \mathrm{~L}^{-1}$, and $7.78 \pm 0.26$ at the entry of the RBC. The flow rate was set at $51.6 \mathrm{~L} \mathrm{~d}^{-1}(\mathrm{HRT}=0.97 \mathrm{~d})$, and the main characteristics of the wastewater were as follows: $\mathrm{NH}_{4}{ }^{+}-\mathrm{N}=880 \pm 69 ; \mathrm{NO}_{2}{ }^{-} \mathrm{N}=0.15 \pm 0.10 ; \mathrm{NO}_{3}{ }^{-}-\mathrm{N}=0.53$ $\pm 0.32 ; \mathrm{COD}=572 \pm 121$ (all in $\mathrm{mg} \mathrm{L}^{-1}$ ).

Chemical Analyses. The concentrations of $\mathrm{NH}_{4}{ }^{+}-\mathrm{N}$ (determined as total ammonia nitrogen, $\mathrm{NH}_{4}{ }^{+}-\mathrm{N}+\mathrm{NH}_{3}-\mathrm{N}$ ) and total Kjeldahl- $\mathrm{N}$ were determined via standard procedures (23). Influent and effluent nitrate and nitrite concentrations were determined using an ion chromatograph (Dionex, Sunnyvale, CA). The DO was measured with a digital, portable DO meter (Endress-Hauser, COM 381). COD and volatile and total suspended solids (VSS and TSS) were determined according to standard methods (24).

DNA Extraction and Purification, Polymerase Chain Reaction (PCR), and Denaturing Gradient Gel Electrophoresis (DGGE). Total DNA was extracted from biomass of the two inocula (ABIL and anaerobic sludge) and from the RBC and FFBR biofilm as described before (25). A nested PCR technique entailed specific amplification of 16S rRNA genes of members of the $\beta$-subdivision of $\mathrm{AAOB}$ and the planctomycetes (PLA) in the first round, followed by reamplification using a primer set for all Bacteria during the second PCR round (26). The PCR primers and conditions and the DGGE protocols were as described before (22).

Quantification with Real-Time PCR. Real-time PCR was based on the principle of Heid et al. (27). For quantification of different bacterial groups, amplification was performed in $25-\mu \mathrm{L}$ reaction mixtures by using buffers supplied with the qPCR Core Kit for Sybr Green I as described by the 
suppliers (Eurogentec, Liège, Belgium) in MicroAmp Optical 96-well reaction plates with optical caps (PE Applied Biosystems, Nieuwerkerk a/ d IJssel, The Netherlands). Primers CTO189fAB/CTO189fC and CT0654r (AAOB), PLA40f and P518r (planctomycetes), and P338f/P338-IIf and P518r (Bacteria) were used for quantification at an optimal primer concentration of respectively 300,100 , and $150 \mathrm{nM}$. The latter were chosen after evaluation of the PCR results when using different primer concentrations. PCR temperature program for $\mathrm{AAOB}$, planctomycetes, and bacteria was as follows: 50 ${ }^{\circ} \mathrm{C}$ for $2 \mathrm{~min}, 95^{\circ} \mathrm{C}$ for $5 \mathrm{~min}$, followed by 40 cycles of $95^{\circ} \mathrm{C}$ for $15 \mathrm{~s}, 57^{\circ} \mathrm{C}$ (AAOB) or $56^{\circ} \mathrm{C}$ (planctomycetes) or $53^{\circ} \mathrm{C}$ (bacteria) for $30 \mathrm{~s}$, and $60^{\circ} \mathrm{C}$ for $1 \mathrm{~min}$. Template DNA in triplicate reaction mixtures was amplified and monitored with an $\mathrm{ABI}$ Prism SDS 7000 instrument (PE Applied Biosystems, Nieuwerkerk a/d IJssel, The Netherlands). Standard curves were constructed after real-time PCR amplification of quadruplicate samples of five different DNA concentrations ranging from $4.5 \times 10^{4}$ to $4.5 \times 10^{6}$ copies of DNA per well for $\mathrm{AAOB} /$ bacteria and from $7.5 \times 10^{4}$ to $7.5 \times 10^{8}$ copies of DNA per well for planctomycetes were used. A 667bp fragment of a Nitrosomonas sp. 16S rDNA sequence (Accession No. AF525953) was generated as a template for the standard curve for quantification of $A A O B$ and Bacteria, while a 732-bp fragment of a planctomycete sp. 16S rDNA sequence (Accession No. AY167666) was generated for planctomycetes quantification. Excellent correlation coefficients (>0.99) were obtained for both standard curves and slopes of -3.81 and -3.40 were generated for AAOB/Bacteria and planctomycetes, respectively. The amount of rDNA copies of $A A O B$ and planctomycetes was normalized to the total number of bacterial rDNA molecules to obtain AAOB and planctomycetes fractions.

Fluorescence In Situ Hybridization (FISH) and Confocal Scanning Laser Microscopy (CSLM). Specific emphasis was on the detection of AAOB (using probe NSO190, which targets ammonia-oxidizing $\beta$-proteobacteria) and the planctomycetes (using probe PLA886, targeting planctomycetes but not covering the known anammox branch, and PLA46, which targets most planctomycetes including the anammox branch). Detailson probes, hybridization conditions, and microscopic techniques were described before (22).

\section{Results}

Start-up Strategy for the RBC Reactor. The RBC reactor performance is described for a 258-d period from start-up (Figure 2A,B). During the first 47 days (HRT $=2 \mathrm{~d}$ ) after nitrifying biomass inoculation, the load was gradually increased from 55 to $300 \mathrm{mg}$ of $\mathrm{N} \mathrm{L}^{-1} \mathrm{~d}^{-1}$. The incoming $\mathrm{NH}_{4}{ }^{+}$was oxidized completely to $\mathrm{NO}_{3}{ }^{-}$(no $\mathrm{NO}_{2}{ }^{-}$detected), and no $\mathrm{N}$ loss was measured. The bulk dissolved oxygen (DO) during this period was $3.0 \pm 0.5 \mathrm{mgL}^{-1}$, and the $\mathrm{pH}$ was $7.72 \pm 0.24$.

On day 47, the granular anaerobic biomass was added, and for about $14 \mathrm{~d}$ the load was controlled at $300 \mathrm{mg}$ of $\mathrm{N}$ $\mathrm{L}^{-1} \mathrm{~d}^{-1}$. When the load was increased to $396 \mathrm{mg}$ of $\mathrm{N} \mathrm{L}^{-1} \mathrm{~d}^{-1}$ (day 61) there was a temporary increase in effluent $\mathrm{NO}_{2}$ concentration (130 mg N L-1), but full nitrification was reestablished within a few days (day 79). $\mathrm{N}$ losses during this period wereless than $20 \mathrm{mg}$ of $\mathrm{N} \mathrm{L}^{-1} \mathrm{~d}^{-1}$. Another load increase on day 98 (to $601 \mathrm{mg}$ of $\mathrm{N} \mathrm{L}^{-1} \mathrm{~d}^{-1}$ ) and on day 105 (to $961 \mathrm{mg}$ of $\mathrm{N} \mathrm{L}^{-1} \mathrm{~d}^{-1}$ ) produced transient high effluent $\mathrm{NO}_{2}^{-}$concentrations (>200 $\mathrm{mg}$ of $\mathrm{N} \mathrm{L}^{-1}$ ), but the $\mathrm{N}$ removal rate increased to about $250 \mathrm{mg}$ of $\mathrm{N} \mathrm{L}^{-1} \mathrm{~d}^{-1}$. Throughout operation, $\mathrm{pH}$ was controlled between 7.8 and 8.0 via the influent $\mathrm{NaHCO}_{3}$, which avoided $\mathrm{NH}_{3}$ stripping (further minimized by the slow disks rotation and concomitant low turbulence). To counter the rising $\mathrm{NO}_{3}{ }^{-}$production (day 127 ), we attempted to impose higher $\mathrm{O}_{2}$ limitation. Hence, the water level in the reactor was lifted by $2.5 \mathrm{~cm}$ (day 133), increasing disks submergence from $58 \%$ to $69 \%$. This seriously impaired nitrification. The total (sum of aerobic and anaerobic) ammonium oxidation rate rapidly dropped from 1060 to 440 mg of $\mathrm{NH}_{4}{ }^{+}-\mathrm{N} \mathrm{L}^{-1} \mathrm{~d}^{-1}$. To reestablish nitrification, the water level was returned to the original level (day 152), and the load was decreased to $923 \mathrm{mg}$ of $\mathrm{N} \mathrm{L}^{-1} \mathrm{~d}^{-1}$. Nitrification fully restored (day 170) and the load was incrementally increased up to $2.04 \mathrm{~g}$ of $\mathrm{N} \mathrm{L}^{-1} \mathrm{~d}^{-1}$. Both effluent $\mathrm{NH}_{4}{ }^{+}$and $\mathrm{NO}_{2}{ }^{-}$ remained constantly below $30 \mathrm{mg}$ of $\mathrm{N} \mathrm{L}^{-1}$, whilethe effluent $\mathrm{NO}_{3}{ }^{-}$concentration continuously decreased from day 170 onward. The latter was likely due to a steadily increasing amount of $\mathrm{NO}_{2}{ }^{-}$being reduced to $\mathrm{N}_{2}$ (and a small amount of $\mathrm{NO}_{3}{ }^{-}$) by AnAOB instead of being fully oxidized to $\mathrm{NO}_{3}^{-}$ by NOB. The load increase from 0.923 to $2.04 \mathrm{~g}_{\text {of }} \mathrm{N}^{-1} \mathrm{~d}^{-1}$ was paired with an increase in removal rate from 348 (35\%) to 1795 (88\%) mg of $\mathrm{N} \mathrm{L}^{-1} \mathrm{~d}^{-1}$, respectively (Figure2B). During the last period (day 247-258), the aerobic and anoxic ammonium oxidation rate were calculated at 1172 and 858 mg of $\mathrm{N} \mathrm{L}^{-1} \mathrm{~d}^{-1}$, respectively, using eqs $1-3$. The bulk dissolved oxygen concentration decreased gradually with increasing load to $0.31 \pm 0.18 \mathrm{mg}$ of $\mathrm{O}_{2} \mathrm{~L}^{-1}$ at the end. The $\mathrm{NO}_{3}{ }^{-}$production rate at the end of this period was $240 \mathrm{mg}$ of $\mathrm{NO}_{3}{ }^{-}-\mathrm{N} \mathrm{L}^{-1} \mathrm{~d}^{-1}\left(0.12 \mathrm{~mol}\right.$ of $\mathrm{NO}_{3}{ }^{-} / \mathrm{mol}$ of $\mathrm{NH}_{4}{ }^{+}$oxidized $)$.

Treatment of theSludgeDigestor Effluent. After the 258- $d$ period of synthetic wastewater treatment under lab-scale controlled conditions, the reactor was moved to treat a sludge digestor effluent on-site. Dueto the fact that no temperature, $\mathrm{pH}$, and DO control were applied, reactor conditions varied significantly when the load changed. The mixed liquor temperature during the 58- $d$ experimental period was 14.0 $\pm 3.1^{\circ} \mathrm{C}$ due to low ambient temperature, especially during the night (October-November). U nder steady-state conditions, the reactor load was $909 \pm 48 \mathrm{mg}$ of $\mathrm{NH}_{4}^{+}-\mathrm{N} \mathrm{L}^{-1} \mathrm{~d}^{-1}$. Under such loading conditions and a $\mathrm{DO}$ and $\mathrm{pH}$ of respectively $0.96 \pm 0.12 \mathrm{mg}$ of $\mathrm{O}_{2} \mathrm{~L}^{-1}$ and $8.03 \pm 0.34$, the RBC reactor removed $423 \pm 39 \mathrm{mg}$ of $\mathrm{N} \mathrm{L}^{-1} \mathrm{~d}^{-1}$ without an adaptation period (Figure $3 \mathrm{~A}, \mathrm{~B}$ ). During these periods, the effluent $\mathrm{NH}_{4}{ }^{+}, \mathrm{NO}_{2}{ }^{-}$, and $\mathrm{NO}_{3}^{-}$were respectively (mg of $\mathrm{N}$ $\mathrm{L}^{-1}$ ) $419 \pm 58,15 \pm 4$, and $36 \pm 10$ (influent $\mathrm{NH}_{4}{ }^{+}-\mathrm{N}=880$ $\pm 69 \mathrm{mg} \mathrm{L}^{-1}$ ). The reactor aerobic and anoxic ammonium oxidation rate were thus estimated (using eqs $1-3$ ) to be respectively 278 and $192 \mathrm{mg}$ of $\mathrm{N} \mathrm{L}^{-1} \mathrm{~d}^{-1}$, resulting in $47 \%$ $\mathrm{N}$ removal at the given load. The steady-state system was disturbed several times by accidental interruptionsin feeding for one or more days (indicated with arrows in Figure 3) and once by an electrical failure, which caused a stop in disk rotation for $1 \mathrm{~d}$ (day 17 ). When no feed was supplied, the DO gradually increased to more than $5 \mathrm{mg}$ of $\mathrm{O}_{2} \mathrm{~L}^{-1}$ (due to a lack of oxygen consumption), and concomitantly the $\mathrm{pH}$ decreased to values below 6.5. The latter was probably due to an imbalanced nitrification and anammoxof the remaining $\mathrm{NH}_{4}{ }^{+}$(>400 mg of $\mathrm{N} \mathrm{L}^{-1}$ ) in the reactor at the moment the feed was stopped. $\mathrm{No} \mathrm{NO}_{2}{ }^{-}$peaks were observed during the feed stops, these were however observed after restarting the feed ( $>500 \mathrm{mg}$ of $\mathrm{NO}_{2}^{-}-\mathrm{N} \mathrm{L}^{-1}$ at day 14). Despite these peaks of the toxic nitrite, autotrophic $\mathrm{N}$ removal was reinstalled soon (within 1 or $2 \mathrm{~d}$ ) after the $\mathrm{DO}$ and $\mathrm{pH}$ were back to steady-state level. The reactor also recovered from the disk rotation stop on day 17 without loss of activity. The effluent COD was on average $481 \mathrm{mg} \mathrm{L}^{-1}$, indicating that $91 \mathrm{mg} \mathrm{L}^{-1}$ COD was consumed via either aerobic processes or via heterotrophic denitrification.

Use of RBC Biocatalyst to Anoxically Treat a Synthetic $\mathbf{N H}_{4}{ }^{+} / \mathbf{N O}_{2}{ }^{-}$Wastewater. The anoxic FFBR, in which the $\mathrm{O}_{2}$ input via the feed solution and through reactor parts was estimated to be $0.1 \mathrm{mg} \mathrm{L}^{-1} \mathrm{~d}^{-1}$ based on a batch reactor run without biomass, also demonstrated immediate $\mathrm{N}$ removal on the $\mathrm{NH}_{4}{ }^{+} / \mathrm{NO}_{2}{ }^{-}$mixture (Figure 4). Feeding of the reactor was started with a mixture of $100 \mathrm{mg}$ of $\mathrm{N}^{-1}$ of both $\mathrm{NH}_{4}{ }^{+}$ and $\mathrm{NO}_{2}^{-}$(load of $53.2 \mathrm{mg}$ of $\mathrm{N} \mathrm{L}^{-1} \mathrm{~d}^{-1}$ ). The $\mathrm{N}$ load to the 

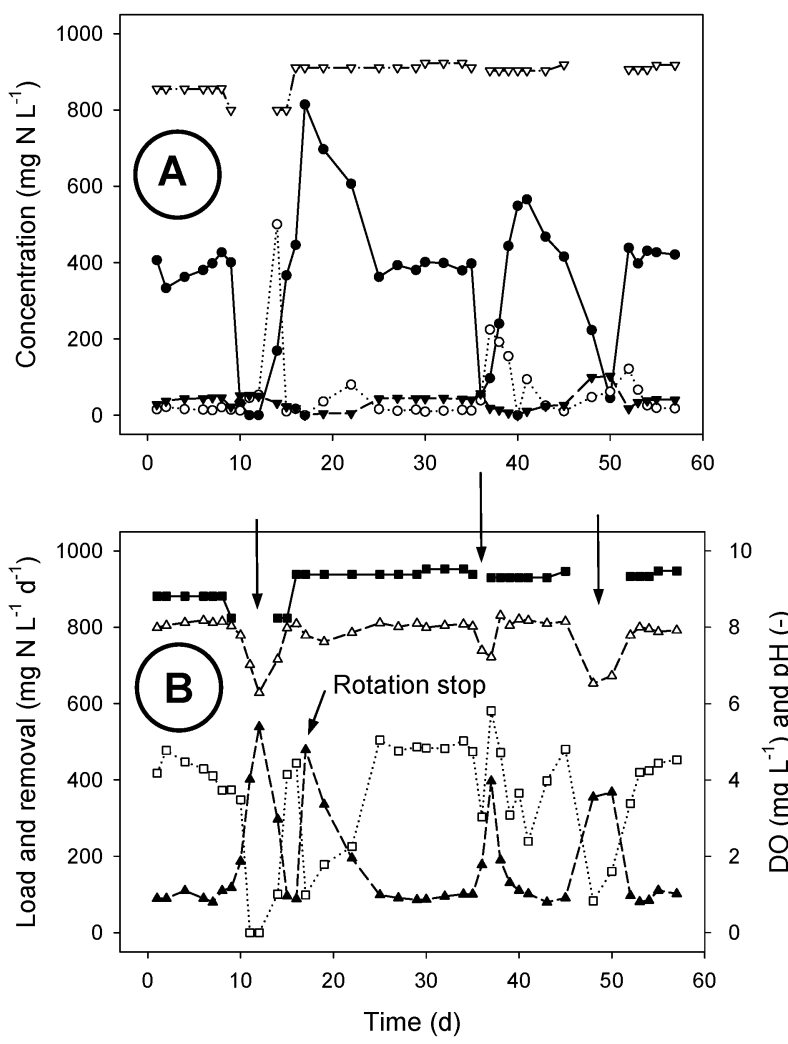

FIGURE 3. Performance of the RBC reactor during treatment of a sludge digestion effluent. (A) Effluent $\mathrm{NH}_{4}{ }^{+}(O), \mathrm{NO}_{2}^{-}(\mathrm{O})$, and $\mathrm{NO}_{3}^{-}$ $(\nabla)$ concentrations and influent $\mathrm{NH}_{4}{ }^{+}(\nabla)$. (B) Load ( $\square$ ) and removal $(\square)$ of the RBC reactor related to the $D O(\Delta)$ and $\mathrm{pH}(\triangle)$ profile at the outflow point of the reactor. Arrows indicate process disturbances, three times no load $w$ as applied, while once the disk rotation was stopped for $1 \mathrm{~d}$.

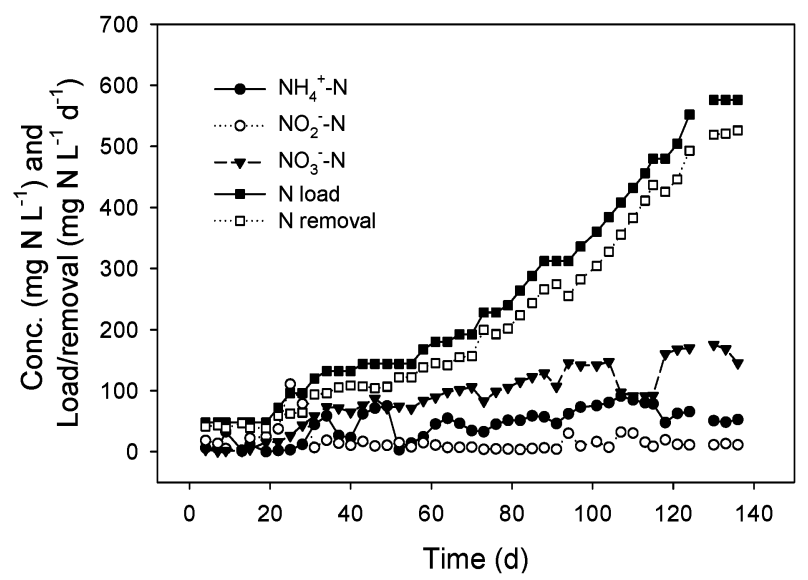

FIGURE 4. Performance of the anoxic FFBR started up with carrier material inoculated with RBC mixed community. Effluent inorganic $\mathrm{NH}_{4}{ }^{-}-\mathrm{N}, \mathrm{NO}_{2}^{-}-\mathrm{N}$, and $\mathrm{NO}_{3}{ }^{-}-\mathrm{N}$ concentrations are show $\mathrm{n}$ vs the reactor load and $\mathrm{N}$ removal of the FFBR.

reactor was gradually increased, ensuring that the effluent $\mathrm{NO}_{2}{ }^{-}-\mathrm{N}$ concentration did not reach toxic levels. Literature information on nitrite toxicity toward AnAOB shows that these bacteria are partially inhibited and totally inactivated at 50 and $100 \mathrm{mg}$ of $\mathrm{NO}_{2}^{-}-\mathrm{N} \mathrm{L}^{-1}$, respectively (4). No load increase was imposed when effluent $\mathrm{NO}_{2}{ }^{-}-\mathrm{N}$ concentration exceeded $30 \mathrm{mg}$ of $\mathrm{N} \mathrm{L}^{-1}$. This value was arbitrarily chosen as a safety value, based on literature and own previous experiences with comparable enrichment cultures. Hence, the load could be slowly increased to $319 \mathrm{mg}$ of $\mathrm{N} \mathrm{L}^{-1} \mathrm{~d}^{-1}$ (day 80 ) with an average removal of $85 \%$. From day 80 on,

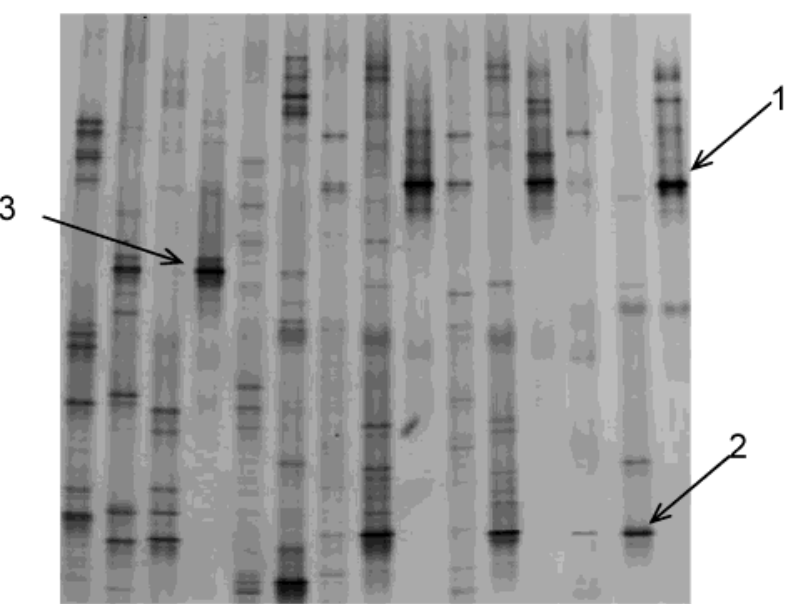

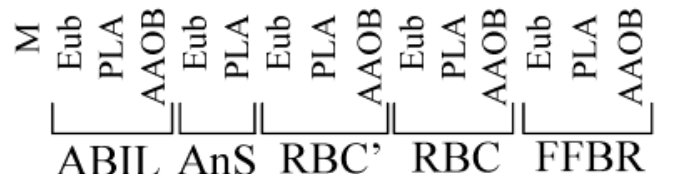

FIGURE 5. DGGE-diversity profiles of all bacteria (Eub), $\beta$-proteobacterial ammonia oxidizers (AAOB), and planc tomycetes (PLA) of different bioreactors and the inocula. $A B I L$, a nitrifying enric hment culture; AnS, granular anaerobic sludge; RBC, rotating biological contactor; FFBR, fixed-film bioreactor; $R B C^{\prime}$ is from a second labscale $\mathrm{RBC}$ reactor described in ref $11 . \mathrm{M}$, molecular size marker; 1 , dominant $A A O B$ in all autotrophic $N$ removal systems, clone AOB 4 (AF525953); 2, dominant planctomycete in the same systems, clone PLA16 (AY167666); 3, dominant AAOB in the ABIL inoculum.

the load could be doubled over $50 \mathrm{~d}$ without significant effluent $\mathrm{NO}_{2}^{-}$peaks, which al ways remained below $10 \mathrm{mg}$ of $\mathrm{N} \mathrm{L}^{-1}$. The specific anammox rate in the FFBR was $434 \mathrm{mg}$ of $\mathrm{NH}_{4}{ }^{+}-\mathrm{N}$ (g of VSS) ${ }^{-1} \mathrm{~d}^{-1}$ (total specific removal rate 828 mg of $\mathrm{N}$ ( $\mathrm{g}$ of VSS) ${ }^{-1} \mathrm{~d}^{-1}$ ) and was 3-fold higher than that of the RBC biomass, measured in batch assays (Table 1 ). The specific aerobic ammonium oxidation potential of the FFBR biomass decreased by a factor of 4.6 as compared to the RBC biomass (Table 1 ) and could only be measured after an aerobic incubation lag phase of $24 \mathrm{~h}$ (results not shown).

Quantification of Bacterial GroupsviaQuantitativePCR in Inocula and Reactors. The AAOB rRNA gene copies per nanogram of total community DNA dropped from $263 \pm 115$ $\times 10^{3}$ in $\mathrm{ABIL}$ to $146 \pm 80 \times 10^{3}$ in the RBC and further to $35 \pm 10 \times 10^{3}$ in theFFBR, both measured in biomass samples at the end of the reactor runs (Table 1). The planctomycetes rRNA gene copies number increased from the inoculum (anaerobic sludge) to the RBC and the FFBR, but, because the planctomycetes comprise both anaerobic/aerobic and organotrophic/ lithotrophic bacteria, interpretation of these values is difficult. Relative to the total bacterial rRNA gene copy number, planctomycete rRNA gene copies make up $19.2 \%$ in the RBC and $36.7 \%$ in the FFBR. The ratio of AAOB to planctomycetes $16 \mathrm{~S}$ rRNA gene copies dropped from 1.10 in the RBC to 0.23 in the FFBR (Table 1 ).

Microbial Shiftsin the Dominant Populations of Inocula, RBC, and Anoxic Reactor. Both inocula produced a diverse (eu)bacterial DGGE band pattern, both showing some 15 separate bands (Figure 5). This was also the case for the RBC patterns, but for theFFBR fewer bands were observed. Using the CTO primer set specific for AAOB, one dominant DGGE band (no. 3in Figure 5) was observed in ABIL, corresponding with the dominant bacterial band. No PCR product was obtained for theanaerobic inoculum with these CTO primers. In the RBC biofilm, a new AAOB clone was dominant (RBC and $\mathrm{RBC}^{\prime}$ in Figure 5), which was sequenced (clone AOB4, AF525953) and closely related (more than 98\%) to a number 

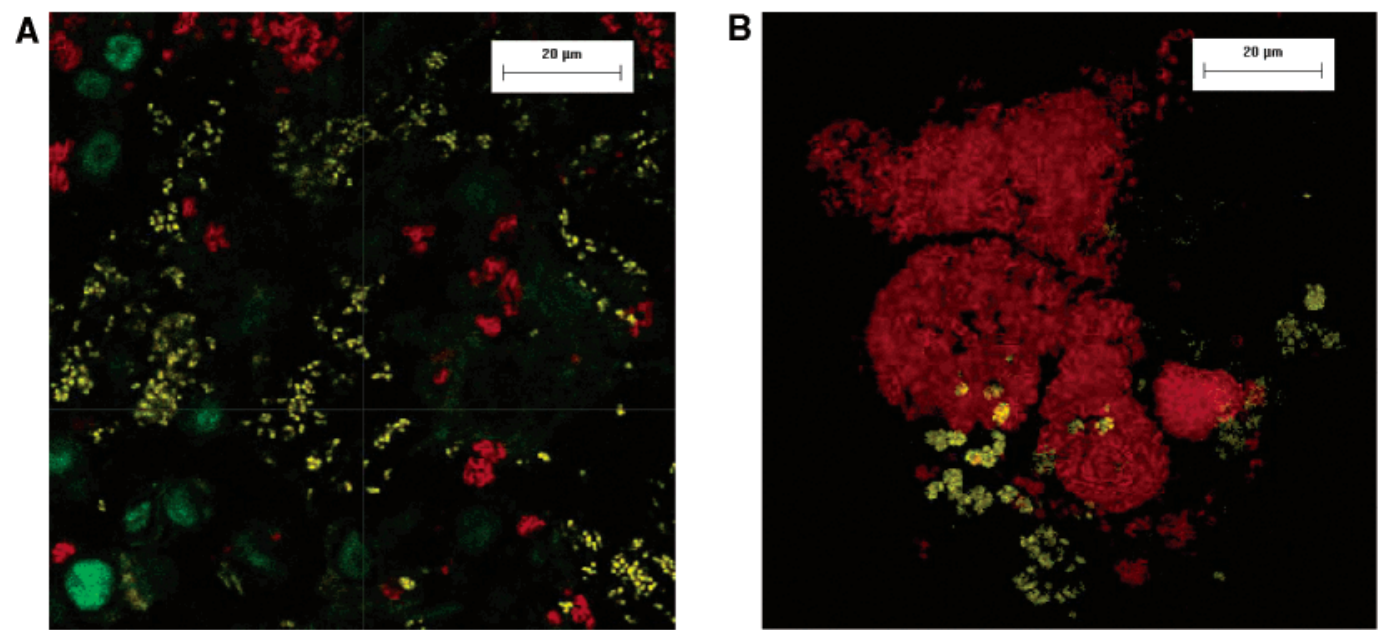

FIGURE 6. Representative CSLM -FISH images of RBC (A) and FFBR (B) biomass. (A) Probes used are PLA886-FLU0 (green), NS0190-Cy3 (yellow ), and PLA46-Cy5 (red). (B) Only the N S0190-Cy3 and PLA46-Cy5 w ere used (no detection of PLA886-FLUO signals in other hybridizations).

of Nitrosomonas sp. Surprisingly, clone AOB4 was also detected in the FFBR biomass (Figure 5, no. 1), and the AAOB DGGE pattern of this reactor showed high resemblance with that of the RBC reactor. ThePLA community in both inocula was diverse, but neither of the inocula was dominated by the same fragment dominating the RBC reactors (Figure 5). The latter (clone PLA16, AY167666) had 98\% sequence similarity with the known AnAOB Kuenenia stuttgartiensis and also dominated the PLA community in the anoxic FFBR. In general, the DGGE pattern of the RBC biomass described in this paper also shows high similarity with the biomass from a previous RBC setup described (11), shown as RBC' in Figure 5.

FISH and Microscopy. In the RBC samples, AAOB (NSO190 signal) as well as planctomycetes (PLA46 and PLA886 signals) were abundantly present (Figure 6A). For the planctomycetes, PLA46 and PLA886 targeted different organisms in the biofilm. Also in the anoxic FFBR reactor $A A O B$ signals were present, albeit in a relatively lower amount than the planctomycetes (hybridizing with probe PLA46) (Figure 6B). PLA886 signals were consistently absent in the FFBR biofilm (not shown).

\section{Discussion}

For the OLAND start-up experiment, an RBC was preferred over other types of reactors because it combines the advantages of abiofilm reactor (good biomass retention, high stability toward shock loads, fixed positioning of bacteria and cell-to-cell contact, etc.) with ease of operation (simple control strategies, no reactor clogging, low maintenance, etc.). The start-up procedure comprised two main elements: providing the two types of biocatalytic inocula and biofilm formation under controlled $\mathrm{N}$ loading rate. As nitrifying inoculum we used $A B I L$, in which the $A A O B$ constituted on average $35.8 \%$ of the total DNA, but any biomass (either suspended or as a biofilm) originating from a nitrifying reactor treating an $\mathrm{NH}_{4}{ }^{+}$-rich wastewater poor in organic carbon can be a suitable inoculum for AAOB. The latter were added first because their growth rate is typically faster (0.04-0.08 $\left.\mathrm{h}^{-1} ; 28\right)$ than those of AnAOB $\left(0.003 \mathrm{~h}^{-1} ; 29\right)$, and they are required to produce one of the substrates for the AnAOB $\left(\mathrm{NO}_{2}{ }^{-}\right)$. Due to the thin biofilm and relatively high bulk DO values (around $3 \mathrm{mg}$ of $\mathrm{O}_{2} \mathrm{~L}^{-1}$ ) during the first period (47 d), both $\mathrm{AAOB}$ and $\mathrm{NOB}$ were active and $\mathrm{NO}_{3}{ }^{-}$was produced (period 1 in Figure 2). These conditions were chosen to maximizetheinitial growth of a nitrifying biofilm. The reactor $\mathrm{pH}$ was stabilized at $7.8-8.0$ with $\mathrm{NaHCO}_{3}$ in the influent to compensate for the acid production during nitrification. In general, a pH of 8 or slightly higher is ideal for autotrophic $\mathrm{N}$ removal. During the first period, no $\mathrm{N}$ losses weremeasured in the liquid stream. The anaerobic inoculum was added after a stable, sufficiently thick nitrifying biofilm had developed (day 47). An alternativeinoculum could bebiomass obtained from an oxygen-limited or anoxic reactor where $\mathrm{NH}_{4}{ }^{+}$and traces of $\mathrm{NO}_{2}{ }^{-}$have been simultaneously present for a long period of time. At the point of anaerobic biomass addition, it was crucial to ensure the presence of both $\mathrm{NH}_{4}{ }^{+}$ and $\mathrm{NO}_{2}^{-}$and to create partially anoxic conditions in the biofilm. To that effect, the $\mathrm{NH}_{4}{ }^{+}$load was increased to promote rapid $\mathrm{O}_{2}$ consumption in the outer biofilm layer. At the same time, the effluent $\mathrm{NO}_{3}{ }^{-}$concentration significantly dropped, and a peak of $\mathrm{NO}_{2}{ }^{-}$was observed (onset of period 5 , Figure $2 \mathrm{~A}$ ). This is most likely the result of an imbalance between $A A O B$ and NOB activity, the latter apparently being limited at the higher $\mathrm{NH}_{4}{ }^{+}$load. This limitation could be due to the higher $\mathrm{O}_{2}$ affinity of AAOB as compared to NOB (30) and thus lower $\mathrm{O}_{2}$ availability for $\mathrm{NO}_{3}{ }^{-}$formation and/or the increasing competition between $\mathrm{NOB}$ and $\mathrm{AnAOB}$ for $\mathrm{NO}_{2}{ }^{-}$ dueto changes in the oxygen profile of thethickening biofilm at higher $\mathrm{N}$ loads. From that moment on, removal of $\mathrm{NH}_{4}{ }^{+}$I $\mathrm{NO}_{2}{ }^{-}$started, and $\mathrm{N}$ losses from the liquid stream up to 1795 mg of $\mathrm{N} \mathrm{L}^{-1} \mathrm{~d}^{-1}$ weremeasured at theend of theexperimental period. Considering the low initial planctomycete content of the anaerobic inoculum $\left(25 \pm 8 \times 10^{3}\right.$ copies of rRNA ( $\mathrm{ng}$ of total DNA $)^{-1}$ ), some initial $\mathrm{N}$ loss was probably caused by conventional denitrification of $\mathrm{NO}_{2}^{-}$with biomass decay products. However, the increasing $\mathrm{N}$ loss at higher reactor $\mathrm{N}$ loads and the high total amount of $\mathrm{N}$ eliminated during the 258- $\mathrm{d}$ period (1804 $\mathrm{g}$ of $\mathrm{N}$ or an average of $140 \mathrm{mg}$ of $\mathrm{N}$ $\mathrm{L}^{-1} \mathrm{~d}^{-1}$ ) strongly suggest that the largest part of the $\mathrm{N}$ is removed autotrophically. Denitrification of $\mathrm{NO}_{2}{ }^{-}$with biomass $\left(\mathrm{CH}_{2} \mathrm{O}_{0.5} \mathrm{~N}_{0.15}=24.1 \mathrm{~g} \mathrm{~mol}^{-1}\right)$-COD would have required a minimum of $2020 \mathrm{~g}$ of biomass, which was not available. Additional batch tests (Table 1 ) confirmed an anammox activity of the RBC biomass of $4.9 \pm 0.7 \mathrm{mg}$ of $\mathrm{N}\left(\mathrm{g}\right.$ of VSS) ${ }^{-1}$ $\mathrm{h}^{-1}$, which is only about $17 \%$ of the maximum specific anoxic ammonium oxidation activity of known Anammox bacteria (31) but of same order as measured for other autotrophic N removing biofilms $(7,32)$. In the studied RBC biofilm, the planctomyceterRNA gene copies only made up $19.2 \%$ of the total DNA based on real-time PCR quantification while the Anammox culture by Strous et al. (31) was nearly $80 \%$ enriched in AnAOB based on FISH analysis, possibly explaining the differences in measured specific anammox activity in the two systems. FISH analysis further suggested that AnAOB may only have constituted a fraction of the 
planctomycetes because PLA886 signals (specific for most planctomycetes, except the AnAOB cluster; 33) were also abundant (Figure 6A), which would further reduce the estimated fraction of AnAOB in the total community. Nitrate was formed during the whole experimental period, in the beginning due to NOB activity, however at the end almost completely by $A n A O B$, as the amount of $\mathrm{NO}_{3}{ }^{-}$formed per amount of $\mathrm{NH}_{4}{ }^{+}$oxidized was 0.12 , almost equal to the predicted amount (eqs 1-3).

The dominant $A A O B$ found in the RBC biofilm (accession number AF525953) showed 98\% sequence similarity with that present in a full-scale autotrophic $\mathrm{N}$ removing $\mathrm{RBC}$ reactor treating an $\mathrm{NH}_{4}{ }^{+}$-rich leachate (7). To provide further evidence that the abundant planctomycetes in the RBC biofilm were responsible for the anammoxreaction, an anoxic fixed film bioreactor on $\mathrm{NH}_{4}{ }^{+} / \mathrm{NO}_{2}{ }^{-}$was started with carrier material that was submerged in the RBC reactor for 1 month prior to its use in the reactor. The DGGE pattern in Figure 5 clearly shows the same dominant planctomycete signal in the RBC as in the FFBR, suggesting its involvement in anammox. This planctomycete signal was also identical to thedominant PLA signal from another $\mathrm{RBC}$ reactor (Accession No. AY167666), and its sequence was closely related (98\% partial 16S rRNA gene sequence similarity) to Kuenenia stuttgartiensis, one of two well-described $\operatorname{AnAOB}(6,34)$. With respect to the inocula, the RBC and the FFBR biomass composition shifted toward new dominant $A A O B$ and planctomycete species. The anammox activity of the FFBR biomass in an anaerobic batch test was nearly three times higher than that of the RBC biomass (Table 1). FISH analysis suggested that planctomycetes (which would includeAnAOB) were present in high densities (Figure 6B), and real-time PCR quantification confirmed their abundance (36.7\% of the total rRNA gene copy number). PLA886 signals disappeared from the biofilm under strict anoxic conditions (in theFFBR), and the role of these bacteria in the $\mathrm{N}$ removal process in the RBC biofilm is therefore unclear. The FFBR was highly performant, easy in construction and operation, and had a very high biomass retention capacity (between 90 and 95\%). The specific anammox capacity of the FFBR biomass (in reactor assay) was approximately $60 \%$ of the maximum reported anammox activity (688 $\mathrm{mg}$ of $\mathrm{NH}_{4}{ }^{+}-\mathrm{N}$ (g of VSS) ${ }^{-1}$ $\mathrm{d}^{-1}$ ) (29). This type of reactor could thus be an alternative for the SBR reactor $(29,35,36)$ or the trickling filter (6) frequently used for anammox. Theactivity measured in batch test with dislodged biomass waslower, potentially associated with physical damage to the biofilm and exposure of the AnAOB to oxygen during removal of the biofilm. The physical damagewas caused by brushing off the biofilm, which created a loose-structured biomass and presumably altered both positioning and density of the active bacteria. The latter was also shown to have a marked influence on AnAOB activity in other studies (4). The removal stoichiometry in batch test (Table1) varied slightly between the RBC and theFFBR, which is most likely caused by some heterotrophic denitrification of oxidized $\mathrm{N}$ compounds with electron donors derived from decaying obligatory aerobic biomass or small differences in the anoxic $\mathrm{NO}_{2}{ }^{-}$to $\mathrm{NO}_{3}{ }^{-}$conversion by the AnAOB present in the biomass.

FISH analysis of the FFBR biomass indicated the continuous presence of $A A O B$ under anoxic conditions (Figure $6 \mathrm{~B})$, and $A A O B$ activity was further confirmed by an aerated batch test, although the $\mathrm{NO}_{2}{ }^{-}$producing activity was only initiated after a lag phase of $24 \mathrm{~h}$ (Table 1). Quantitative PCR revealed a larger fraction of PLA than AAOB in the FFBR biomass. It should however be noted that similar densities of AAOB rRNA gene copies were found in the FFBR $(35 \pm 10$ $\times 10^{3}$ copies (ng of total DNA) ${ }^{-1}$ ) and in the anaerobic sludge (AnS) $\left.\left(27 \pm 7 \times 10^{3} \text { copies ( } n g \text { of total DNA }\right)^{-1}\right)$. Comparison of biomass RT-PCR numbers from different reactors is in any case subject to a certain degree of uncertainty (shown by the high standard deviation on the RT-PCR quantifications), which could be caused by the difficulty to obtain comparable DNA extraction from different biomass samples. No aerobic ammonia-oxidizing activity was however measured for the AnS during aeration for $5 \mathrm{~d}$. Thereasons for the continued presence of AAOB under anoxic condition, found by us and others (6), remain elusive. Potentially they engage in anoxic autotrophic metabolism (37-39), perform other yet-to-be determined metabolic reactions, or survive on traces of oxygen that entered the system. The latter was estimated to be only $0.1 \mathrm{mg}$ of $\mathrm{O}_{2} \mathrm{~L}^{-1} \mathrm{~d}^{-1}$, allowing an extremely low, negligible oxidation rate of $0.038 \mathrm{mg}$ of $\mathrm{NH}_{4}{ }^{+}$ $\mathrm{L}^{-1} \mathrm{~d}^{-1}$ to $\mathrm{NO}_{2}{ }^{-}$, in case this amount is solely used by AAOB.

For a 2-month period, the RBC reactor proved capable of significant $\mathrm{N}$ removal from a sludge digestor effluent under ambient temperature conditions $\left(14 \pm 3^{\circ} \mathrm{C}\right)$. Under continuous load, AAOB and AnAOB activities were both significantly lower than under lab-scaleconditions (respectively 4.2 and 4.5 times lower). The steady-state DO (around $1 \mathrm{mg}$ of $\mathrm{O}_{2} \mathrm{~L}^{-1}$ ) and $\mathrm{pH}$ (around 8), which were obtained without external control, were highly similar to values obtained in other biofilm reactors $(3,40)$ and shown to be around the optimal values for autotrophic $\mathrm{N}$ removal in biofilm reactors $(32,41)$. In contrast to the anammox reactors, several process disturbances did not inhibit the autotrophic $\mathrm{N}$ removal because autotrophic $\mathrm{N}$ removal was reestablished without external actions. Even high DO concentrations of more than $5 \mathrm{mg} \mathrm{L}^{-1}$ during several days or low pH values $(<6.5)$, causing temporary inhibition of the AnAOB (Figure 3), did not affect the performance once the load conditions were re-instated. $\mathrm{NOB}$ activity appeared small in view of the low effluent $\mathrm{NO}_{3}{ }^{-}$ concentration. $\mathrm{NO}_{3}{ }^{-}$removal by simultaneous denitrification was probably minor due to the continuous presence of $\mathrm{NO}_{2}{ }^{-}$ as an electron acceptor and a total COD removal rate of 94 mg of COD L $\mathrm{L}^{-1} \mathrm{~d}^{-1}$ (aerobic breakdown + denitrification). The robustness and stability of the biofilm reactor for $\mathrm{N}$ removal was acceptable, yielding removal rates of around $500 \mathrm{mg}$ of $\mathrm{N} \mathrm{L}^{-1} \mathrm{~d}^{-1}$, despite the fact that it generally took a few days to recover from process disturbances and that the removal rate did not increase with time. The continuously low effluent $\mathrm{NO}_{2}{ }^{-}$concentration during stable reactor operation (Figure 3 ) indicates that the overall $\mathrm{N}$ elimination could be limited by the nitrification efficiency of the AAOB at low temperature and DO conditions rather than an inhibition of the AnAOB. The latter was also concluded for similar $\mathrm{N}$ elimination experiments in two separated reactors (35). Further pilot-scale implementations will determine under what conditions the RBC approach for complete autotrophic $\mathrm{N}$ removal can be optimized.

\section{Acknowledgments}

This research was funded by the Flemish Institute for the Improvement of Scientific-Technological Research in the Industry (IWT). The authors thank Katrien Crul, Nico Boon, Farida Doulami, and Han Vervaeren for help with the molecular analysis and FISH and Lutgarde Raskin, Hendrik Nollet, and Geert Lissens for the critical reading of this paper. We also thank Bjarke Bak Christensen of the Danish Veterinary and Food Administration (Søborg, DK) for access to the confocal scanning laser microscope.

\section{Literature Cited}

(1) Helmer, C.; Kunst, S.; Juretschko, S.; Schmid, M. C.; Schleifer, K.-H.; Wagner, M. Water Sci. Technol. 1999, 39, 13.

(2) Mulder, A.; Van De Graaf, A. A.; Robertson, L. A.; Kuenen, J. G. FEMS Microbiol. Ecol. 1995, 16, 177.

(3) Siegrist, H.; Reithaar, S.; Koch, G.; Lais, P. Water Sci. Technol 1998, 38, 241. 
(4) Jetten, M. S. M.; Wagner, M.; Fuerst, J.; van Loosdrecht, M. C. M.; Kuenen, G.; Strous, M. Curr. Opin. Biotechnol. 2001, 12, 283.

(5) Strous, M.; Fuerst, J. A.; Kramer, E. H. M.; Logemann, S.; Muyzer, G.; van de Pas-Schoonen, K. T.; Webb, R.; Kuenen, J. G.; Jetten, M. S. M. Nature 1999, 400, 446.

(6) Schmid, M.; Twachtmann, U.; Klein, M.; Strous, M.; Juretschko, S.; Jetten, M.; Metzger, J. W.; Schleifer, K. H.; Wagner, M. Syst. Appl. Microbiol. 2000, 23, 93.

(7) Egli, K.; Fanger, U.; Alvarez, P. J. J.; Siegrist, H.; van der Meer, J. R.; Zehnder, A. J. B. Arch. Microbiol. 2001, 175, 198.

(8) Helmer-Madhok, C.; Schmid, M.; Filipov, E.; Gaul, T.; Hippen, A.; Rosenwinkel, K. H.; Seyfried, C. F.; Wagner, M.; Kunst, S. Water Sci. Technol. 2002, 46, 223.

(9) Kuai, L.; Verstraete, W. Appl. Environ. Microbiol . 1998, 64, 4500.

(10) Pynaert, K.; Sprengers, R.; Laenen, J.; Verstraete, W. Environ. Technol. 2002, 23, 353.

(11) Pynaert, K.; Wyffels, S.; Sprengers, R.; Boeckx, P.; Van Cleemput, O.; Verstraete, W. Water Sci. Technol. 2002, 45, 357.

(12) Hippen, A.; Helmer, C.; Kunst, S.; Rosenwinkel, K. H.; Seyfried, C. F. Water Sci. Technol. 2001, 44, 39.

(13) Sliekers, A. O.; Derwort, N.; Gomez, J. L. C.; Strous, M.; Kuenen, J. G.; Jetten, M. S. M. Water Res. 2002, 36, 2475.

(14) Hellinga, C.; Schellen, A.; Mulder, J. W.; van Loosdrecht, M. C. M.; Heijnen, J. J. Water Sci. Technol. 1998, 37, 135.

(15) Bernet, N.; Dangcong, P.; Delgenes, J. P.; Moletta, R. J. Environ. Eng. 2001, 127, 266.

(16) Wyffels, S.; Boeckx, P.; Pynaert, K.; Verstraete, W.; Van Cleemput, O. J. Chem. Technol. Biotechnol. 2002, 78, 412.

(17) Verstraete, W.; Philips, S. Environ. Pollut. 1998, 1, 717.

(18) van Dongen, U.; Jetten, M. S. M.; van Loosdrecht, M. C. M. Water Sci. Technol. 2001, 44, 153.

(19) Grommen, R.; Van Hauteghem, I.; Van Wambeke, M.; Verstraete, W. Aquaculture 2002, 211, 115.

(20) Sekiguchi, Y.; Kamagata, Y.; Syutsubo, K.; Ohashi, A.; Harada, H.; Nakamura, K. Microbiology (U.K.) 1998, 144, 2655.

(21) Third, K. A.; Sliekers, A. O.; Kuenen, J. G.; Jetten, M. S. M. Syst. Appl. Microbiol. 2001, 24, 588.

(22) Pynaert, K.; Smets, B. F.; Wyffels, S.; Beheydt, D.; Siciliano, S. D.; Verstraete, W. Appl. Environ. Microbiol. 2003, 69, 3626.

(23) Bremner, J. M.; Keeney, R. D. Anal. Chem. Acta 1965, 32, 485.

(24) Greenberg, A. E.; Clesceri, L. S.; Eaton, A. D. Standard methods for theexamination of water and wastewater, 18th ed.; American Public Health Association, American Water Works Association, Water Environment Federation: Washington, D.C., 1992.

(25) Boon, N.; Goris, J.; De Vos, P.; Verstraete, W.; Top, E. M. Appl. Environ. Microbiol. 2000, 66, 2906
(26) Boon, N.; Goris, J.; De Vos, P.; Verstraete, W.; Top, E. M. Appl. Environ. Microbiol. 2001, 67, 1107.

(27) Heid, C. A.; Stevens, J.; Livak, K. J.; Williams, P. M. GenomeRes 1996, 6, 986.

(28) Barnes, D.; Bliss, P. J. Biological Control of Nitrogen in Wastewater Treatment; E \& FN Spon: London, 1983.

(29) Strous, M.; Heijnen, J. J.; Kuenen, J. G.; Jetten, M. S. M. Appl. Microbiol. Biotechnol. 1998, 50, 589.

(30) Laanbroek, H. J.; Gerards, S. Arch. Microbiol. 1993, 159, 453.

(31) Strous, M.; Kuenen, J. G.; Jetten, M. S. M. Appl. Environ. Microbiol. 1999, 65, 3248

(32) Koch, G.; Egli, K.; Van der Meer, J. R.; Siegrist, H. Water Sci. Technol. 2000, 41, 191.

(33) Neef, A.; Amann, R.; Schlesner, H.; Schleifer, K.-H. Microbiology (U.K.) 1998, 144, 3257.

(34) Schmid, M.; Schmitz-Esser, S.; Jetten, M. S.; M.; Wagner, M. Environ. Microbiol. 2001, 3, 450.

(35) Fux, C.; Boehler, M.; Huber, P.; Brunner, I.; Siegrist, H. J. Biotechnol. 2002, 99, 295.

(36) Jetten, M. S. M.; Schmid, M.; Schmidt, I.; Wubben, M.; van Dongen, U.; Abma, W.; Sliekers, O.; Revsbech, N. P.; Beaumont, H.J. E.; Ottosen, L.; Volcke, E.; Laanbroek, H. J.; Campos-Gomez, J. L.; Cole, J.; van Loosdrecht, M. C. M.; Mulder, J. W.; Fuerst, J.; Richardson, D.; van de Pas, K.; Mendez-Pampin, R.; Third, K.; Cirpus, I.; van Spanning, R.; Bollmann, A.; Nielsen, L. P.; Op den Camp, H.; Schultz, C.; Gunderson, J.; Vanrolleghem, P.; Strous, M.; Wagner, M.; Kuenen, J. G. Rev. Environ. Sci. Biotechnol. 2002, 1, 51.

(37) Schmidt, I.; Hermelink, C.; van de Pas-Schoonen, K.; Strous, M.; Op den Camp, H. J.; Kuenen, J. G.; Jetten, M. S. M. Appl. Environ. Microbiol. 2002, 68, 5351.

(38) Bock, E.; Schmidt, I.; Stuven, R.; Zart, D. Arch. Microbiol. 1995 $163,16$.

(39) Abeliovich, A.; Vonshak, A. Arch. Microbiol. 1992, 158, 267.

(40) Helmer, C.; Tromm, C.; Hippen, A.; Rosenwinkel, K. H.; Seyfried, C. F.; Kunst, S. Water Sci. Technol. 2001, 43, 311.

(41) Hao, X. D.; Heijnen, J. J.; van Loosdrecht, M. C. M. Biotechnol. Bioeng. 2002, 77, 266

Received for review June 18, 2003. Revised manuscript received October 29, 2003. Accepted November 28, 2003.

$\mathrm{ESO30081+}$ 